\title{
Strategic Integration of Business Structures Based on the Principles of Single Institutional-Economic Space
}

\author{
Tronina I.A.* \\ Oryol state University named after I.S. Turgenev \\ Oryol, Russia \\ E-mail: irina-tronina@yandex.ru \\ Morozova O.I. \\ Oryol state University named after I.S. Turgenev \\ Oryol, Russia \\ E-mail: 777olia09@mail.ru \\ Knyazeva V.A. \\ Oryol state University named after I.S. Turgenev \\ Oryol, Russia \\ E-mail: knyazeva_va@mail.ru
}

\author{
Semenikhina A.V. \\ Oryol state University named after I.S. Turgenev \\ Oryol, Russia \\ E-mail: an-semenikhina@rambler.ru \\ Musatova I.V. \\ Oryol state University named after I.S. Turgenev \\ Oryol, Russia \\ E-mail: irina-mousatova@yandex.ru \\ Kononova E.E. \\ Oryol state University named after I.S. Turgenev \\ Oryol, Russia \\ E-mail: len.kononowa@yandex.ru
}

\begin{abstract}
Strategic integration of business structures in the conditions of transfer of innovative knowledge is focused on the development and creation of stable positions of the regional sector of the economy. However, today, the effectiveness of institutional interaction processes remains not high. This is primarily due to the lack of effective methodological tools based on the principles of a single institutional-economic space, which determines the relevance of the research problem. The study purpose is theoretical justification and development of modern methodological support of innovative project integration targeted at the enhancement of knowledge transfer efficiency and diffusion into the institutional-economic space on the principles of innovative partnership. System approach is the leading method of studying business structure integration processes in the context of innovative knowledge transfer as it allows considering non-linear nature of innovative development and the concept of integrated formation and dynamic capabilities of business structures. As a result of the study, the following tasks were solved: an approach to creating a single institutionaleconomic space for the interaction of integration participants was proposed; a model solution for the institutionalization of an innovative project was formed taking into account the situational knowledge base, the possibility and expediency of integration development; developed a contextual diagram of knowledge management in the process of integration development of enterprises; the structure of the regional integrated innovation complex is shown; the methodology for assessing the importance of integration / concentration of innovative knowledge to increase the institutionalization of business structures in the region is substantiated. These results will contribute to the solution of an important theoretical and practical task relating to innovative knowledge transfer performance in strategically integrated enterprises based on institutionalization. Study materials may be used as methodological support for the justification of areas of institutionalization and innovative development of integrated structures of the real economy.
\end{abstract}

Keywords - enterprise, integration processes, innovative knowledge transfer, institutional-economic space, integrated business structure.

\section{INTRODUCTION}

The modern level of business development may be described as uneven and unstructured since the use of the traditional methodological support of innovative project integration in the institutional-economic space does not bring expected results [6].

The domestic economy has sufficient potential to foster the development of innovative knowledge transfer in strategically integrated enterprises. However, for all that, Russian businesses still face the problems that hamper the integration of business structures and, as a result, promotion of innovative knowledge. These problems are rooted in the lack of an efficient tool to enhance the performance of institutional interaction [15].

\section{METHODS AND MATERIALS}

The study has used modern innovative economy theories, papers, monographs and articles of foreign and home scientists, synopses of theses on the problems of integrated system innovative development management in the context of the knowledge-based economy.

The problems of integration development and their influence on innovative economic growth are addressed in numerous papers of both foreign and home authors. For example, the theoretical and methodological framework of the strategic development of integrated business structures has been elaborated in papers by I.I. Dyukov, A.A. Kolobov, A.I. Pushkar, Yu.E. Zhukov, A.A. Pilipenko, I. Ansoff, etc. $[5,9,17,25]$. 
The conceptual framework of the knowledge-based economy is studied in papers by L.A. Lavrov, E.V. Popov, B.V. Salikhov, E.N. Khramov, Nancy Dickson and other scientists [11, 16, 19, 23, 27].

Innovative development of economic entities is studied in papers by S.V. Valdaytsev, L.M. Gokhberg, E. Carayannis, E. Grigoroudis, N.D. Kondratyev, E.V. Yurchenko and many others $[2,3,7,10,24]$.

Scientific views of the writing team were greatly influenced by major works of foreign and national scientists in integrated system innovative development management in the context of the knowledge-based economy. Some of them include works by T.E. Kuznetsova, S.A. Izmalkova, A.Yu. Kirov, I.V. Kirova, M.V. Leonova, A.I. Shinkevich, A.M. Makarov, Melissi Clemmons Rumizen, L.I. Ushvitsky, M. Boisot, whose ideas are justly used as the basis of economic science and practice $[2,8,12-14,20,21,26]$.

Despite a major degree of elaboration of the theory of the stated problems, there are still matters unsolved that relate to methodological support of innovative process integration targeted at the enhancement of knowledge transfer efficiency and diffusion into the institutional-economic space.

\section{RESULTSAND DISCUSSION}

In the current context, orientation at the strategic integration of business structures results in the actualization of a new type of competition targeted at the domestic resource market of a new structural complex. Correspondingly, consideration of knowledge as one of the main resources brings about an intensive need to elaborate a knowledge management system in the context of integrated unity operation. It means that the elaboration of a strategic program of integrated structure development requires that the management system introduce certain innovative aspects of the activity, especially during transformations and transitions between system conditions that may be described as a cyclic process of integrated business structure (IBS) development.

Integration process extension inevitably results in the prevalence of the management of intangible assets over tangible ones and retargeting of the business structures strategic integration control system at such assets as knowledge, company image, trademark, patents [1]. Knowledge management implies the settlement of two main types of tasks: contribution to the acceleration of interactions or cost saving with a simplified knowledge use procedure; promotion of innovation implementation, creation of new products and services based on more efficient knowledge sharing among IBS participants.

Thus, one may agree with the authors of [7] who say that it is relevant knowledge that shapes competitive advantages of business structures as only knowledge becomes the competence base in the context of the information economy. The problems of knowledge creation, management, and classification in the context of information economy both in terms of an individual economic entity and integrated business structures are addressed quite in detail in a number of works
$[12,8,14,16,23,26]$. At the same time, in terms of IBS development strategy elaboration and presentation of the business structure strategic integration control system as a set of levers and tools combining resource and system knowledge of actors [1], innovative knowledge transfer control system requires close discussion. Note that an "actor" is understood to mean a social unit, agent of economic or social relations that takes part in strategic integration.

Innovation should be addressed as the process of creating alternatives to the development of any open system. Random nature in possibility generation limits former definitions of human influence on dynamics and management of this process. The writing team has elaborated a model solution of the innovative project institutionalization that implies interactive review of possible partners in innovative solution elaboration. The chart is shown in figure 1.

The authors assume that this action will be made by some actor. Establishment of the relevant institutional interaction base, to be more exact, common institutional-economic interaction space (CIEIS) and elaboration of certain control concepts are ongoing at the same time.

If the proposed approach is accepted, it is necessary to ensure consistency of innovative development generation and commercialization and creation of an innovative communications network as an integral aggregate of economic relations of innovation subjects that have connections, which define IBS integrated properties. This network must be built subject to the provisions on the dependence of a knowledge acquisition method on a strategy type adopted in an organization provided in [8].

Accordingly, business structures are divided into intelligence operators (orientation at market and maximizing innovation), defenders (dominance of limited lines), analyzers (novation simulation) and editors (strategy change) [20]. This is achieved by the corresponding positioning of both integration process initiating subject and all its possible counter-agents in 3-D coordinates "innovative potential knowledge sharing form - nature of strategic interaction". These coordinates will define the view of the presence of each individual participant in IBS. Besides, this positioning allows assessing the feasibility of innovative process integration and institutionalization by considering dual reduced matrix assemblies as it is shown in table I below.

The IBS development strategy concept is accordingly expanded to its representation as a position shared by most IBS participants and it acts as a result of a group action.

This approach to the strategy enables integration of the innovation management system in the business structure strategic integration control system by way of: innovative cycle combination with existing business processes; continuous improvement of IBS content by combining supply chain reconfiguration with optional exclusion of individual participants; creation of information network of innovations, which ensures common perception of the innovation introduction space; activity enhancement of business structures engaged in innovative processes. 


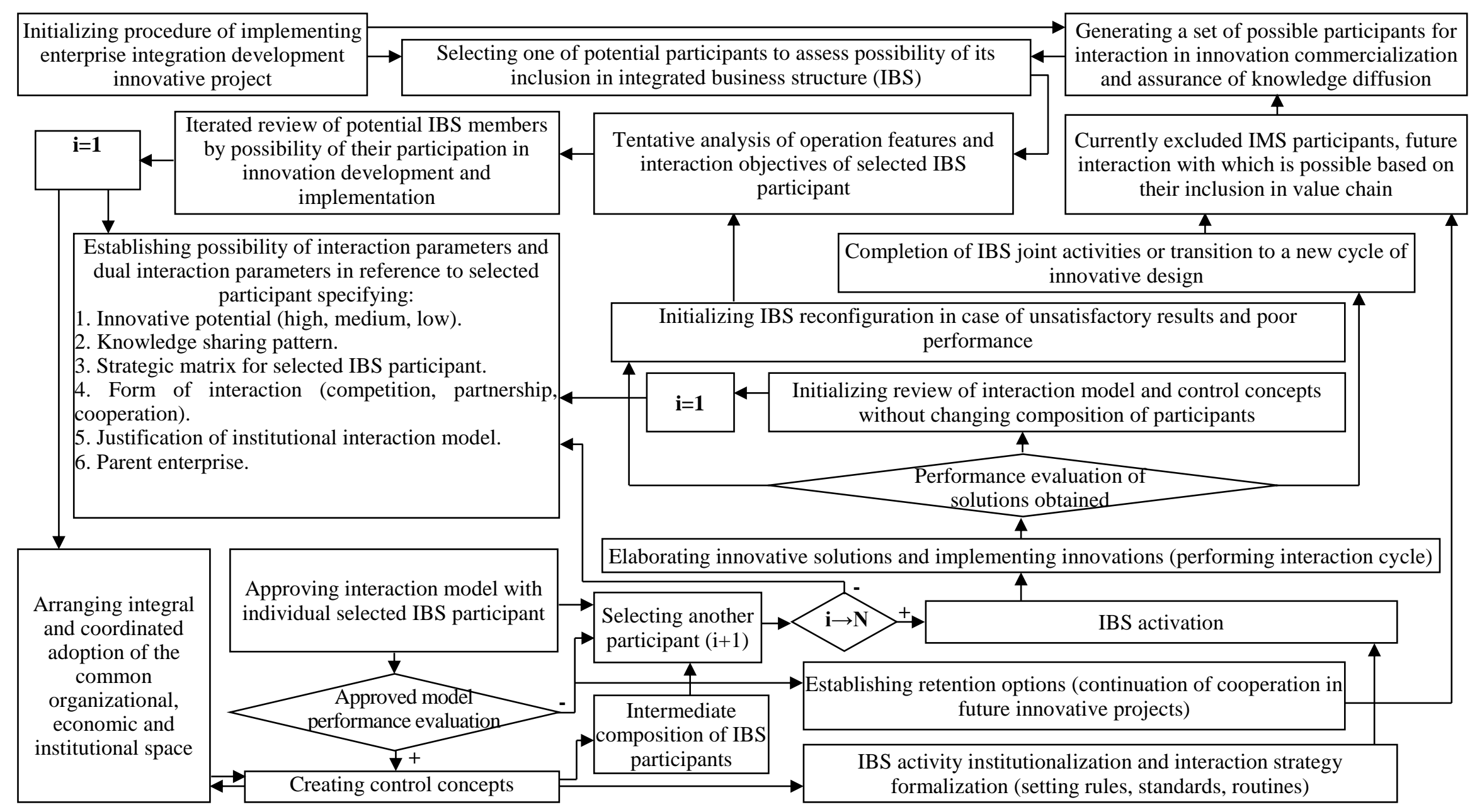

Fig. 1. Model solution of innovative project institutionalization subject to situational knowledge base, integration development capability and feasibility, original development 
TABLE I. SITUATIONAL KNOWLEDGE BASE OF SYSTEM INTEGRATION DEVELOPMENT CAPABILITY (FRAGMENT), ORIGINAL DEVELOPMENT

\begin{tabular}{|c|c|c|c|}
\hline Type & $\begin{array}{c}\text { Situation } \\
\text { description }\end{array}$ & $\begin{array}{c}\text { Form of } \\
\text { competition }\end{array}$ & $\begin{array}{l}\text { Predicted situation and } \\
\text { interaction feasibility }\end{array}$ \\
\hline 1 & $\begin{array}{l}\text { Networking. Peer } \\
\text { tuition synergy use. } \\
\text { Innovative } \\
\text { cooperation. }\end{array}$ & $\begin{array}{l}\text { Cooperation and } \\
\text { coordination of } \\
\text { actions. Free } \\
\text { exchange of } \\
\text { public and private } \\
\text { core information }\end{array}$ & $\begin{array}{l}\text { Knowledge overflow } \\
\text { from a public partner. } \\
\text { Variety and flexibility of } \\
\text { innovations with } \\
\text { available knowledge } \\
\text { protection. Diffusion } \\
\text { through knowledge } \\
\text { intelligence. }\end{array}$ \\
\hline 2 & $\begin{array}{l}\text { Setting up alliances } \\
\text { to study and simulate } \\
\text { knowledge. High- } \\
\text { level access } \\
\text { knowledge sharing. }\end{array}$ & $\begin{array}{l}\text { Joint trustful } \\
\text { actions and } \\
\text { unlimited use of } \\
\text { jointly obtained } \\
\text { innovation } \\
\text { results. }\end{array}$ & $\begin{array}{l}\text { Limited innovation } \\
\text { introduction } \\
\text { compromises. Minor } \\
\text { complexity of corporate } \\
\text { knowledge management } \\
\text { in chosen areas. }\end{array}$ \\
\hline 3 & $\begin{array}{l}\text { Integration of small } \\
\text { business structures } \\
\text { without a clear } \\
\text { dominant actor in the } \\
\text { context of perfect } \\
\text { competition market. }\end{array}$ & $\begin{array}{l}\text { Use of positive } \\
\text { feedback-based } \\
\text { peer tuition } \\
\text { synergy. }\end{array}$ & $\begin{array}{l}\text { Knowledge management } \\
\text { targeted at supporting } \\
\text { innovations. Joint value } \\
\text { creation and setting } \\
\text { experience sharing } \\
\text { networks. }\end{array}$ \\
\hline 4 & $\begin{array}{l}\text { Each partner in } \\
\text { innovative product } \\
\text { development wants } \\
\text { to protect its own } \\
\text { knowledge and } \\
\text { acquire other } \\
\text { partner's experience. }\end{array}$ & $\begin{array}{l}\text { Creation of } \\
\text { information } \\
\text { support systems } \\
\text { for strategic } \\
\text { partnership of } \\
\text { integration hybrid } \\
\text { forms. }\end{array}$ & $\begin{array}{l}\text { In time, the same } \\
\text { innovative potential of } \\
\text { actors may result in both } \\
\text { higher level of } \\
\text { integration and } \\
\text { suspension of } \\
\text { interaction. }\end{array}$ \\
\hline$\ldots$ & 1 & & \\
\hline 19 & $\begin{array}{l}\text { Competitive quasi- } \\
\text { integrative relations } \\
\text { targeted at solution } \\
\text { of a common } \\
\text { problem or } \\
\text { performance of the } \\
\text { same innovative } \\
\text { articles. }\end{array}$ & $\begin{array}{l}\text { Information } \\
\text { exchange within } \\
\text { formal core } \\
\text { information } \\
\text { needed for } \\
\text { mutual relations. }\end{array}$ & $\begin{array}{l}\text { Suspension of an } \\
\text { integrated business } \\
\text { structure after efficient } \\
\text { innovation. Further } \\
\text { collaboration as a higher } \\
\text { level of integration is } \\
\text { possible. }\end{array}$ \\
\hline
\end{tabular}

Direct result-orientation implies that a certain actor, IBS participant, is able to convert knowledge into particular actions that lead to achievement of own or third party's objectives [22]. Indirect orientation implies that a knowledge holder assumes that other IBS participants may use its knowledge to start focused actions. Cooperation of activity systems of different actors must be based on this view. Considering the chart shown in figure 1, it is fair to say that the composition of integrated business structure participants may be reconfigured thanks to the capability of absorption (ability to absorb new knowledge [8]) and abstraction (stored knowledge recombination [14]). Besides, these actors' attributes may be added to strategic matrices.

Thus, in terms of innovation diffusion, establishing connection between interaction regularity of integration participants, level of communication linkages, mutual trust and innovative knowledge sharing is very important. Discussion of combination asymmetry and level of opportunism in the behaviour of CIEIS representatives [17] is a matter of principle. This matter becomes even more relevant when sharing private knowledge that is particularly retained in experience and customs of individual employees. In this case, supporting the economic and information security policy adopted by individual actors is quite a challenge. Possible IBS innovation policy options must be elaborated subject to the methodology of real options in order to impart required flexibility to the integrated unity when developing an innovative product. For example, if an asymmetric IBS is created, the methodology adopted must allow individual participants to acquire the right to transfer intellectual cost or license to the product made (if all its attributes can not be defined as of the innovative product development start) [17].

Pooling of integration and innovative product development processes determines joint strategic alternative development peculiarities to a great degree. Thus, the need to develop flexibility during innovative product development and establishment of the relevant IBS policy has caused a proposition regarding the use of the economic entity dynamic capability concept when elaborating the integration business structure development strategy [17]. The authors' contextual chart of knowledge management based on combination of the concept of actual and dynamic capabilities is shown in figure 2 .

The use of the stated paradigm of dynamic capabilities of business structures allows bringing innovation development and introduction processes even closer to the knowledge management tool. Knowledge is viewed as the main resource that enables production of an innovative product and creation of lasting competitive advantages of an integrated business structure. Accordingly, it should be noted that knowledge as a dynamic resource will have certain additional attributes that must always be viewed as elements of the system of integration restrictions [13, 23].

It should be noted that IBS sees not only innovation diffusion and knowledge transfer, but also concurrent knowledge coordination with capabilities of individual actors and their conversion into a required skill. This is why the key role in innovative product development is played by the distribution of required knowledge and skills among business structures in such a way that each IBS participant is capable of perceiving and efficiently using available information when settling set innovation tasks. Another important problem to IBS is collective generation, joint use and efficient extension of knowledge between business structures.

Thus, information and innovative knowledge concentration significantly affects IBS development management as it allows assessing, predicting and planning required qualitative transition stages, arranging, implementing and controlling innovation creation and introduction, regulating the chaotic manifestations that occur when the technology level changes in order to stabilize business structure operation, eliminate adverse random factors, etc. [13, 23].

The authors believe that an integrated innovation complex may become an efficient structure that enables enhancement of innovative knowledge transfer efficiency in IBS to keep it competitive, to develop it and to perform all kinds of activities in the innovative space [18]. Such complexes are particularly important in the regions that act as a complex system with its peculiarities, innovative product creation and use.

The structure of such regional integrated innovative complex (RIIC) is shown in figure 3 . 


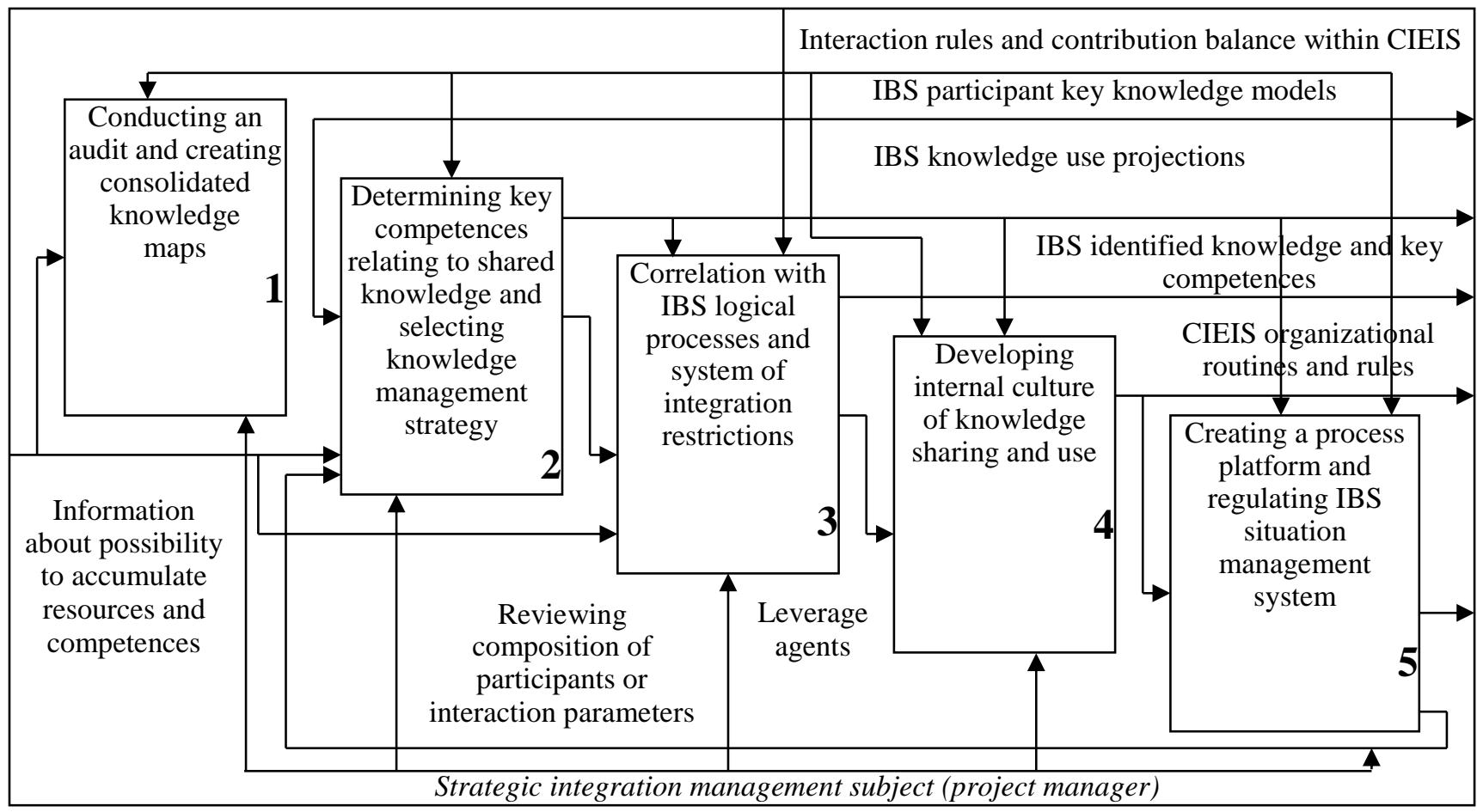

Fig. 2. Contextual chart of knowledge management in the course of integration of development business structures, original development

1. Evaluation of the current regional technology and economic environment.

2. Diagnosis of a problem situation and identification of idle reserves.

3. Elaboration of measures and programs of regional innovative development.

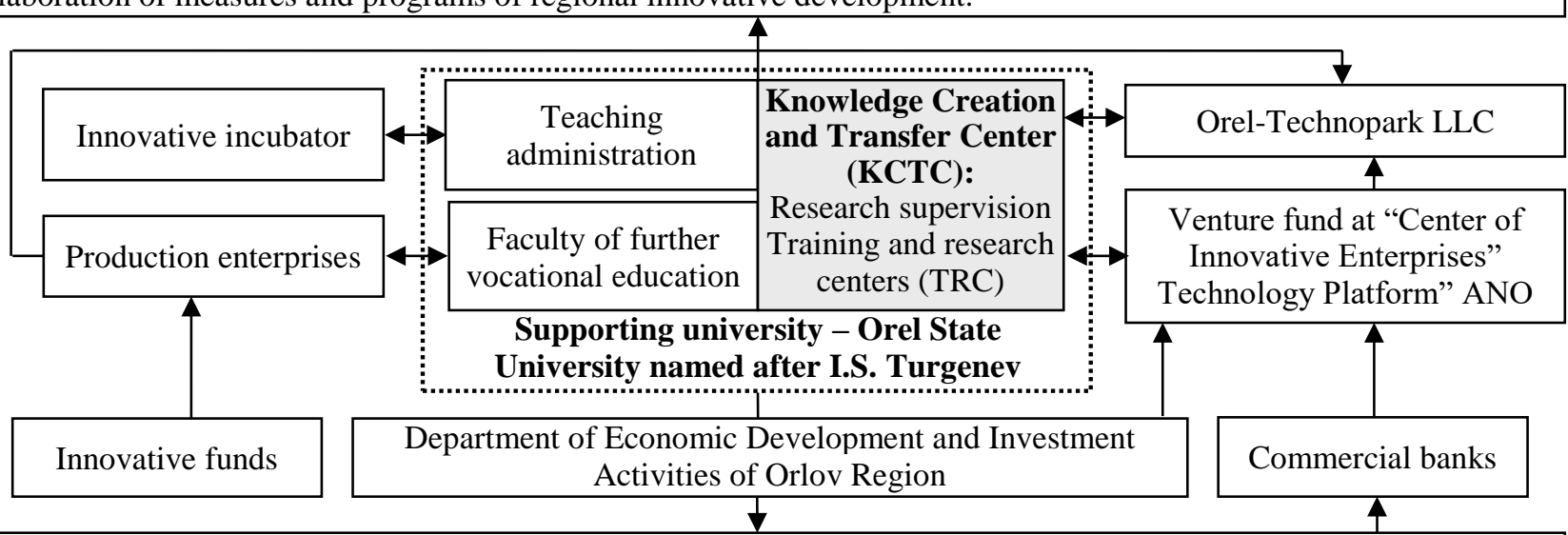

Functions of higher education institutions as structural units of the regional innovative development system

1. Generation of process, product and technology innovations at training and research centers (TRC) of Orel State University named after I.S. Turgenev.

2. Setting up small innovative enterprises based on innovations generated at TRC.

3. Training of competent, innovations-active and responding staff.

4. Certification and standardization of innovative products and articles.

5. Engineering, preproduction, commercial testing, replication.

Fig. 3. Structure of the regional integrated innovative complex, original development 
Thus, integration of the system of adaptive training and research centres, higher educational institutions, industrial parks, venture innovation funds and production enterprises into a common system to enhance innovative knowledge transfer efficiency and create innovative products and technologies allows building up brain capital and implementing knowledge management processes in a comprehensive manner [4].

Importance and necessity of knowledge integration/ concentration to enhance institutionalization of regional innovative projects (by the example of Orlov region) with regard to the local knowledge base, capabilities and feasibility of integration development of business structures was identified during expert evaluation. The following representatives of business communities of the instrumentmaking cluster of Orlov region acted as experts: Fornex CJSC, Branch of Tavrida Electric Group of Companies - Orlov Electrical Engineering Plant, Proton JSC, ProtonElectrotex JSC, Proton-Impuls CJSC, Pumos JSC, Rubin Elektroniki LLC, Nauchpribor NPJSC, BolkhovPlant of Semiconductors OJSC, Syntec LLC, Elebrain NTC LLC, Astron Electronic RPE LLC, Electrotex-IN LLC.

Experts were offered to assess indicators of importance of innovative knowledge integration/concentration for the enhancement of institutionalization of regional business structures developed by the writing team on a 1-5 scale from 1 (lowest) to 5 (highest).Indicators weights were established in line with their level of significance in the integral estimate. Assessment results are given in table II.

TABLE II. RESULTS OF ASSESSING IMPORTANCE OF INNOVATIVE KNOWLEDGE INTEGRATION/CONCENTRATION FOR THE ENHANCEMENT OF INSTITUTIONALIZATION OF BUSINESS STRUCTURES IN ORLOV REGION, ORIGINAL DEVELOPMENT

\begin{tabular}{|c|c|c|c|c|c|c|c|c|}
\hline \multirow[t]{2}{*}{ Indicator } & \multicolumn{5}{|c|}{$\begin{array}{c}\text { Number of } \\
\text { experts, people }\end{array}$} & \multirow{2}{*}{\begin{tabular}{|c} 
Average \\
score
\end{tabular}} & \multirow{2}{*}{ Weight } & \multirow{2}{*}{$\begin{array}{l}\text { Integral } \\
\text { estimate }\end{array}$} \\
\hline & 1 & 2 & 3 & 4 & 5 & & & \\
\hline $\begin{array}{l}\text { Knowledge integration } \\
\text { between KCTC and regional } \\
\text { business structures }\end{array}$ & 4 & 5 & 4 & 5 & 4 & 4.4 & 0.15 & 0.66 \\
\hline $\begin{array}{l}\text { Horizontal knowledge } \\
\text { integration between } \\
\text { individual regional business } \\
\text { structures }\end{array}$ & 5 & 4 & 5 & 4 & 5 & 4.6 & 0.15 & 0.69 \\
\hline $\begin{array}{l}\text { Knowledge integration } \\
\text { between KCTC and } \\
\text { stakeholders }\end{array}$ & 4 & 5 & 4 & 4 & 5 & 4.4 & 0.15 & 0.66 \\
\hline $\begin{array}{l}\text { Knowledge integration } \\
\text { between individual business } \\
\text { structures and stakeholders }\end{array}$ & 5 & 4 & 5 & 5 & 5 & 4.8 & 0.1 & 0.48 \\
\hline $\begin{array}{l}\text { Concentration of intellectual } \\
\text { potential in KCTC }\end{array}$ & 4 & 5 & 5 & 4 & 4 & 4.4 & 0.15 & 0.66 \\
\hline $\begin{array}{l}\text { Concentration of information } \\
\text { about business activities of } \\
\text { regional business structures } \\
\text { in KCTC }\end{array}$ & 5 & 5 & 4 & 5 & 5 & 4.8 & 0.15 & 0.72 \\
\hline $\begin{array}{l}\text { Concentration of external } \\
\text { information about } \\
\text { stakeholders and their needs } \\
\text { in KCTC }\end{array}$ & 5 & 5 & 5 & 4 & 4 & 4.6 & 0.15 & 0.69 \\
\hline Total: Integral estimate & - & - & - & - & - & - & $\sum=1$ & 4.56 \\
\hline
\end{tabular}

The value obtained (4.56) proves high degree of importance of innovative knowledge integration/ concentration for the enhancement of institutionalization of business structures in Orlov region, which, in its turn, allows concluding that knowledge consolidation will contribute to intellectual potential harmonization, development of innovative knowledge transfer in strategically integrated business structures and their efficient interaction in the context of non-linear innovations and transformation of the essence of knowledge-based economy.

\section{CONCLUSIONAND RECOMMENDATIONS}

The article proves that regulation of integration processes by establishing the common institutional-economic space will help business structures pool potential capabilities harmonize their innovation and technology interests and implement joint projects in an efficient manner. This will enhance their innovative development based on the combination of the concept of actual and dynamic capabilities in order to set up a prospective regional knowledge management base.

It has been identified that the Knowledge Creation and Transfer Center is a key aspect of the efficient operation of the regional integrated innovative complex. This center enables integration of training and research centers, higher educational institutions, industrial parks, venture, innovation funds and production enterprises into a common innovative development system to implement knowledge management processes in a comprehensive manner.

The method to assess the importance of innovative knowledge integration/concentration for the enhancement of institutionalization of regional business structures based on the system of local and integral indicators elaborated and tested by the writing team will enable significant influence on innovative knowledge transfer efficiency in strategically integrated structures.

The methodological justification may be recommended to be used to elaborate the Orlov region innovation and technology development program for the period from 2019 to 2030; in activities of the regional integrated innovative complex in Orlov region via the Knowledge Creation and Transfer Center of the supporting institute - Orel State University named after I.S. Turgenev; to assess importance of innovative knowledge integration/concentration for the enhancement of institutionalization of business structures in Orlov region.

The theory elaborated is recommended to be used to teach students of economics of Orel State University named after I.S. Turgenev in the following disciplines: "Management of Innovations", "Modern Problems of Science and Production in Management", "Modern Strategic Analysis".

\section{References}

[1] M.S. Asmolova, S.V. Dedov, "The algorithm to ensure and implement the strategy of the effective management of innovation processes", Proc. of the Voronezh State Univer. of Engineer. Technol., vol. 80, no. 4, pp. pp. 436-440, 2018. Retrieved from: https://doi.org/10.20914/2310-12022018-4-436-440

[2] S.V. Valdaytsev, Management of innovations and intellectual property of the company, 2017.

[3] L.M. Gokhberg, T.E. Kuznetsova, "New innovation policy in the context of economic modernization", J. of the new econ. associat., vol. 7, pp. $141-143,2010$. 
[4] L.V. Davydova, N.Yu. Tarasova, "Institutional structure for ensuring innovative development of the region", Digest-Finance, vol. 10, no. 226, pp. 37-45, 2013.

[5] I.I. Dyukov, Business development strategy, Practical approach. St. Petersburg: Peter, 2012.

[6] Innovative development of Russia: opportunities, problems, prospects. Novosibirsk: ANS "SibAK", 2015.

[7] E. Karayannis, E. Grigorudis, "The four-linked spiral of innovation and "smart specialization": knowledge production and national competitiveness", Foresight, vol. 1, pp. 31-42, 2016.

[8] A.Yu. Kirov, I.V. Kirova, "Using the knowledge management system in the activities of modern companies", Econ., social. and law, vol. 1, pp. 14-19, 2017.

[9] A.A. Kolobov, High-tech management. Integrated production and corporate structures: organization, economics, management, design, efficiency, sustainability. Moscow: Exam, 2008.

[10] N.D. Kondratiev, Large cycles of conjuncture and theory of foresight. Selected Works. Moscow: Economics, 2002.

[11] L.A. Lavrov, Economic growth and human capital. Omsk: Omsk State Univer., 2009.

[12] M.V. Leonova, A.I. Shinkevich, Diffusion of innovations: models and management technologies. Kazan: KNITU, 2014.

[13] A.M. Makarov, E.N. Khramov, "Harmonization of the development of innovative systems as a factor in improving the knowledge management system", Econ. anal.: theory and pract., vol. 36, no. 201, pp. 12-18, 2010.

[14] Melissie Clemmons Rumizen Knowledge management. Moscow: AST, 2004.

[15] O.T. Bogomolov, G.G. Divers, S.Yu. Glazyev, New integral society: general theoretical aspects and world practice. Moscow: LENAND, 2016.
[16] E.V. Popov, M.V. Vlasov, Institutional design of knowledge generation. Yekaterinburg: Instit. of Econ., Ural Branch of the Russ. Acad. of Sci., 2013.

[17] A.I. Pushkar, Yu.E. Zhukov, A.A. Pilipenko, Strategic groups of enterprises: concept, methodology, management. Kharkov: Crossroad, 2006.

[18] Y.A. Salikov, S.V. Vandysheva, L.V. Smarchkova, E.A. Chudakova, "The use of cluster approach in the development of industry in the region", Proc. of the Voronezh State Univer. of Engineer. Technol., vol. 80, no. 4, pp. 493-498, 2018. Retrieved from: https://doi.org/10.20914/2310-1202-2018-4-493-498.

[19] B.V. Salikhov, E.V. Luneva, Social capital as a factor in the innovative development of an enterprise. Moscow: Dashkov and K, 2011.

[20] I.A. Tronina, S.A. Izmalkova, "Methodological approach to creating a modern model for managing the innovative development of integrated systems in the high-tech sector of the economy", Econ. anal.: theory and pract., vol. 18, no. 417, pp. 15-29, 2015.

[21] L.I. Ushvitsky, Innovative development of the Russian economy: problems and prospects. Stavropol: SKFU, 2015.

[22] L.I. Fedulova, "Conceptual foundations of the knowledge economy", Econ. theory, vol. 2, pp. 37-60, 2008.

[23] E.N. Khramov, "Problems and improvement of knowledge management in integrated corporate structures of industry", Econ. anal.: theory and pract., vol. 36, no. 243, pp. 33-40, 2011.

[24] E.V. Yurchenko, Innovation activities of high-tech enterprises. Moscow: Economy, 2009.

[25] H.I. Ansoff, Corporate Strategy. London: Penguin, 1987.

[26] M. Boisot, Knowledge Assets. Securing Competitive Advantage in the Information Economy,. Oxford: Oxford Academ, 1999.

[27] M. Dixon, Nancy Common knowledge: how companies thrive by sharing what they know. Boston, Mass.: Harvard Busin. School Press, 2005 . 